\title{
Paideusis
}

\section{Reconceptualizing Philosophy of Education: A Proposal}

\section{Michael Jackson}

Volume 4, Number 1, 1990

URI: https://id.erudit.org/iderudit/1073388ar

DOI: https://doi.org/10.7202/1073388ar

See table of contents

Publisher(s)

Canadian Philosophy of Education Society

ISSN

0838-4517 (print)

1916-0348 (digital)

Explore this journal

Cite this article

Jackson, M. (1990). Reconceptualizing Philosophy of Education: A Proposal.

Paideusis, 4(1), 5-8. https://doi.org/10.7202/1073388ar

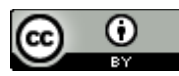

This document is protected by copyright law. Use of the services of Erudit (including reproduction) is subject to its terms and conditions, which can be viewed online.

https://apropos.erudit.org/en/users/policy-on-use/
This article is disseminated and preserved by Érudit.

Érudit is a non-profit inter-university consortium of the Université de Montréal, Université Laval, and the Université du Québec à Montréal. Its mission is to promote and disseminate research.

https://www.erudit.org/en/ 


\section{Reconceptualizing Philosophy of Education: A Proposal}

\section{Michael Jackson \\ Bishop's University}

The purpose of this paper is threefold: first, to review selected recent (and one not so recent) conceptions of philosophy and its role in education in order to place the issues of reconceptualization in context; second, to identify what it is we seek in courses in philosophy of education, especially in initial teachertraining programmes; and, third, to propose an alternative model - something of an "house system" - based on our experience at Bishop's University.

\section{Reconceptualizing}

Perhaps the first recorded revolution in the teaching of philosophy was that of Socrates. He proposed that philosophy could only be understood as the active inquiry of two minds engaged in a search for the truth. The study of a written tradition would distract the mind from the true goal of philosophy, the pursuit of wisdom, and so falsify the discipline by identifying inquiry with the written word. Since there was a written tradition prior to Socrates' time, this constitutes a reconceptualization - perhaps the first - in the history of philosophy, one which concerns directly how the subject should be taught. This first revolution remains the focus of our problem, but now we have a much fuller literature and a tradition with a long written history: how are we to teach this subject in a way which will introduce students to its long and rich history while at the same time cultivating the spirit of inquiry which makes philosophy more than a mere history of ideas? Or, more to the point, how can this be done in a single course in a pre-service, teacher-training programme?

The Socratic problem is well illustrated within philosophy of education in this century. For many people, a philosophy of education was, and still is, identified with a general theory of education, one especially concerned with values and the objectives of an education. On this view, philosophy of education is identified with a variety of systems (for example, Marxist, existential, Christian, and so on) and more or less systematic reflections (sometimes autobiographical) on education.

Such a view was challenged in the famous book by O'Connor (though much in the tradition of Austin and the British analytic philosophers), and so there developed an alternative approach associated, above all, with the work of Peters. The idea was that philosophy of education was something that teachers and students in colleges of education should learn to do for themselves - that teachers should become their own philosophers of education, exercising the skills and dispositions of philosophically informed and sensitive reflective practice. The new emphasis (often reminiscent of Socrates' questioning of Meno) was on language and concepts. So we saw, for example, Peters' frequent discussions of aims in education; a questioning of the meaning, basis and nature of value statements (with a series of resulting problems about what one could legitimately teach in this area); and a series of attempts to distinguish, for example, education from indoctrination or propaganda, and to define key terms like teaching and learning. Values clarification and critical thinking assumed a 
new importance in the curriculum. The new emphasis was on thinking for oneself, and the independence, power and self-reliance which go with that heady notion. The ideas, of course, were not totally without parallel or precedent: Dewey was quite outside British chronicle, and the spirit is definitely Socratic.

More recently, we have seen a third perspective on our field, perhaps in the spirit which O'Connor drew on the "purer" discipline of philosophy. Recent thinking in philosophy has been applied to educational questions. Curriculum theorizing, for example, has been much influenced by conceptions of knowledge resulting from the epistemological work of Kuhn, Toulmin, Rorty, and others. For varying reasons (whether one thinks of Phenix, Hirst, or Soltis), science and mathematics curricula have come to emphasize process, skills and basic concepts; and we now think of languages in terms of "whole language" and "language across the curriculum" as we appreciate recent philosophical shifts in linguistics.

Perhaps each generation or age needs to reconceptualize the discipline for itself just to keep the discipline alive, or more likely, perhaps such reconceptualizations are what define different eras. Somehow, through the changes, the discipline remains.

\section{Expectations}

The Socratic revolution gives us perhaps the two elements which define our expectations for a course or a programme in philosophy of education. We want to marry the tradition of inquiry with the spirit of a free thinker. And, so, four general aims emerge.

We would like to see people emerging from courses in philosophy of education who can think clearly, consistently, logically and objectively. We often think of these as content-neutral skills. But it is not enough to be able to think logically and consistently; we also want people to be sensitive to and reflective about their presuppositions. Maxine Greene makes much of this questioning of what we so easily take for granted. Neither do we wish our graduates to think in a vacuum. For we want them to know something of the history and the literature of their discipline, the history and the literature concerning the philosophical issues which educational discussions raise. And, finally, we would like them to develop a disposition to engage in these activities. To have the ability but not the inclination is not enough. They must want their teaching to be reflective practice.

\section{The "House System"}

Such aims are global and, perhaps, life-long. But many teacher-training programmes provide only a single course in philosophy of education. And this is what gives us our problem - together perhaps with the fact that the most immediate and pressing concems of teachers in training at least seem to them to be practical (like discipline, curriculum, assessment of the learners' problems and of their own teaching, and planning activities for the whole class, for those with problems and for those with special talents). Essentially, my proposal is that we capitalize on this apparent lack of student interest, that we take our philosophical sensitivity to their area of most immediate and pressing concern their practice teaching. 
Students enroll in education programmes (for the most part) because they want to teach. This is what excites them and they put endless effort into their practice teaching. I suggest we meet them on their ground and capitalize on their interest. This is not a particularly radical proposal: it is, after all, there that our concerns have their focus too. What I am proposing is that we take our philosophy of education into the supervision of practice teaching - even to the extent of integrating our courses (or course, as is more often the case) with that supervision. This would commit us to a number of additional activities. Student teaching supervision is notoriously a labour-intensive activity involving travel, long periods of observation and much practical advice. But it does put the university professor (and this is something physical education teachers have always known and capitalized on) where the students' interests are, poised to comment and offer advice when it matters to students who want to know. And, practice-teaching supervision ratios are always low. The nature of the work limits a supervisor to small groups. Let me illustrate this approach with two anecdotes (one from a practice teacher, the other from a beginning teacher) and a description of what we are able to do at Bishop's.

A student teacher comes in to talk after a lecture on campus:

In my school, I'm going to have to teach Catholic religion for the next three weeks. I'm not Catholic; in fact, I think I'm an atheist. I don't know what to do.

This is a problem which has a history and is of some philosophical interest, and she wants to know how to think her way through the problems involved. She is not worried about what to teach; that is clearly defined. And it is not hard to think of ways of making the content interesting. Her problem is how in good conscience she can do this, how she should think about her role as a teacher. Now we are ready for a good discussion, and one which would be of interest to not a few others in the class as well. (After graduation, this student's first teaching position was in a Separate school.)

Another student returned to campus for a visit after his first year teaching.

You know, sir, I spent a lot of time this year working with three of the children. They had more or less dropped out of school. But I kept calling the social services people to bring them to the school. And we worked together. There wasn't anything wrong with them. They weren't stupid or anything. And, at the end, they were reading and participating in class a bit. We were beginning to get somewhere. But I didn't know whether they were ready for the next grade at the end of the year, so I took their cases to a teachers' meeting. And they said to fail them, that they were only Indians anyway. But I didn't feel right about that, and I still don't. I spent all year convincing them they could do the work, and then the system told them they were failures.

It might be that our colleagues in other foundations areas could do something with this case too. But nothing in a textbook or a lecture could ever have the power that one case did. And no one in either case could have posed the questions better. You just have to be there on the spot at the right time, involved in their day to day concerns.

At Bishop's, we have a one-year, forty-five credit, post-degree teacher training programme into which we accept between sixteen and twenty students a year. We can be reasonably selective, so we know the students come to us with 
a degree and a good general background. The programme has a heavy practiceteaching component and each student teaches for three or four weeks in each of five or six schools (both elementary and secondary). All of our staff are involved at least two half days a week in practice-teaching supervision when the students are in the schools. So we are regularly with them in their classrooms, and we meet with them after each observation to talk about their teaching. They typically commute to the co-operating schools in car pools (up to an hour and a quarter each way), and so are together regularly in small groups.

The advantages of this arrangement, as I see them, are three: we are selecting a relatively sophisticated group of students; we are with them on a regular basis; and they are regularly together in groups as well. The plan is not new but has existed for many years, especially under my predecessor, Alan Jones. Because of the students' backgrounds, we can take for granted a great deal of general knowledge in our lectures on campus. The students themselves have much to contribute in our classes on campus from their backgrounds in history, literature, political science and the social sciences. So we can proceed fairly directly to current proposals in education (Boyer, Adler), psychological theories (Ausubel, Bruner), and epistemological questions (Kuhn, Rorty). Because they are together in groups much of the time, the students are able to share their experiences and are encouraged to turn to one another for advice ("You might ask Evelyn what she did with her Grade 3 in Vermont," "Alison's class went on a field trip at Sunnyside").

But the immediate point is that our philosophy of education course can be integrated into their other experiences. Most other teacher-training institutions do not have the small numbers we do - except in practice-teaching supervision where the work requires it. My proposal is that we who teach philosophy of education become more actively involved in the supervision of practice teaching in order that we may work with these smaller groups of students, on a group basis, in situations where we are regularly involved with them in activities which are important to them. A typical foundations professor, then, might well find himself teaching three "sections" of the philosophy of education course by spending two or three mornings a week in schools observing and meeting with his students for practice- teaching - always sensitive to the philosophical issues which can arise - and as little as one hour a week on campus with each of his three "sections" in a small seminar based on his guidance of their readings and discussions as they arise from and relate to their practice-teaching. Effectively, in large faculties of education, this would break students into small groups (somewhat on the lines of a "house system" in schools) in a way that would make these groups meaningful at least for the foundations courses. The professor would be spending more hours at his teaching and supervision (say, twelve hours a week for observing and discussion, three or four more hours for seminars on campus) but with significantly smaller groups, and there would need to be considerable flexibility in the planning of seminar topics. But the outcome could be a clear perception of the relevance of foundations subjects, an integration of theory and practice, and the rewards of working with small groups of enthusiastic students on topics which are of interest and importance to them. 